\title{
Epithelial Morphogenesis during Liver Development
}

\author{
Naoki Tanimizu and Toshihiro Mitaka \\ Department of Tissue Development and Regeneration, Research Institute for Frontier Medicine, \\ Sapporo Medical University School of Medicine, Chuo-ku, Sapporo 060-8556, Japan \\ Correspondence: tanimizu@sapmed.ac.jp
}

\begin{abstract}
Tissue stem/progenitor cells supply multiple types of epithelial cells that eventually acquire specialized functions during organ development. In addition, three-dimensional (3D) tissue structures need to be established for organs to perform their physiological functions. The liver contains two types of epithelial cells, namely, hepatocytes and cholangiocytes, which are derived from hepatoblasts, fetal liver stem/progenitor cells (LPCs), in midgestation. Hepatocytes performing many metabolic reactions form cord-like structures, whereas cholangiocytes, biliary epithelial cells, form tubular structures called intrahepatic bile ducts. Analyses for human genetic diseases and mutant mice have identified crucial molecules for liver organogenesis. Functions of those molecules can be examined in in vitro culture systems where LPCs are induced to differentiate into hepatocytes or cholangiocytes. Recent technical advances have revealed 3D epithelial morphogenesis during liver organogenesis. Therefore, the liver is a good model to understand how tissue stem/progenitor cells differentiate and establish 3D tissue architectures during organ development.
\end{abstract}

Eunctional differentiation/maturation of ep- ithelial cells and establishment of three-dimensional (3D) epithelial tissue structures are indispensable for each organ performing physiological functions. The mammalian liver performs various types of metabolism, produces serum proteins, detoxifies bilirubin and ammonia, and protects the body from infection. Those physiological functions are achieved with $3 \mathrm{D}$ tissue architecture of liver epithelial cells, namely, hepatocytes and cholangiocytes (biliary epithelial cells) (Fig. 1). Hepatocytes and cholangiocytes are derived from hepatoblasts, fetal liver stem/progenitor cells (LPCs), in mid-gestation and then differentiate functionally and structurally. Hepatocytes acquire many physiological functions and are polarized to form hepatic cord structure that is typically one-cell thick in an adult liver. The tiny apical lumen is called bile canaliculus (BC) to which hepatocytes secrete bile juice. Their basal domains face to sinusoidal endothelial cells that have fenestrations, through which hepatocytes efficiently exchange nutrients and metabolites with the bloodstream. Cholangiocytes establish a typical apicobasal epithelial polarity and form intrahepatic bile duct (IHBD) tubules that connect the BCs to the duodenum via hepatic and common bile

Editor: Keith E. Mostov

Additional Perspectives on Cell Polarity available at www.cshperspectives.org

Copyright (C) 2017 Cold Spring Harbor Laboratory Press; all rights reserved; doi: 10.1101/cshperspect.a027862

Cite this article as Cold Spring Harb Perspect Biol 2017;9:a027862 


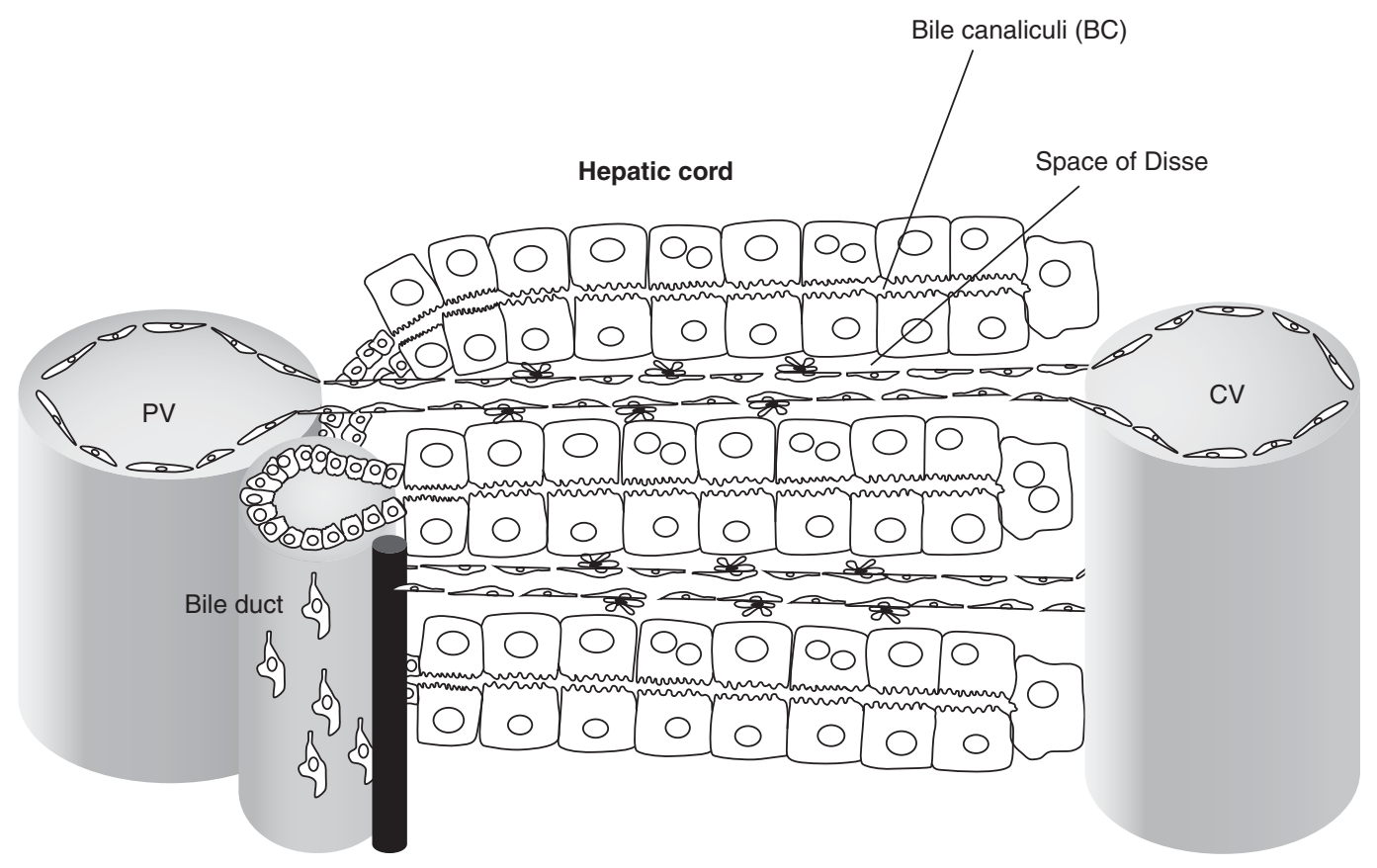

Figure 1. Tissue structures of the liver. Hepatocytes are polarized and form hepatic cords. The apical domains form the thin tubular structure called bile canaliculi (BCs). Hepatocytes secrete bile into the BC. Their basal domains face to sinusoidal endothelial cells via the space of Disse. The space is not abundant in the extracellular matrix (ECM). Cholangiocytes develop the typical epithelial apicobasal polarity and form bile duct tubules adjacent to the portal vein (PV).

ducts to drain bile secreted from hepatocytes. In addition, cholangiocytes modulate the composition of bile by secreting chloride and carbonate ions and by secreting and absorbing water while bile flows through IHBDs.

Analyses for human congenital hepatic diseases and for mutant mice showing abnormal liver development have identified crucial molecules and signals for liver organogenesis. Since immunological definition of liver cells has progressed, LPCs and differentiated epithelial cells can be prospectively isolated from fetal, neonatal, and adult livers and can be used for genomewide gene expression analyses to identify genes that regulate differentiation and morphogenesis of LPCs and liver epithelial cells (Miyajima et al. 2014). In addition, purified LPCs can be induced to differentiate into hepatocytes or cholangiocytes by using in vitro culture systems, in which we can address molecular mechanisms regulating differentiation and morphogenesis of hepatocytes and cholangiocytes (Kamiya et al. 1999; Tanimizu et al. 2003, 2007; Senga et al. 2012).

Liver epithelial morphogenesis in vivo had been mostly studied depending on two-dimensional (2D) tissue sections prepared from developing livers (Lemaigre 2003). As compared with other epithelial organs such as gastrointestinal tracts, kidney, and lung, wherein epithelial morphogenesis proceeds in optically transparent tissue, it is hard to recapitulate and visually follow epithelial morphogenesis of the liver ex vivo because liver tissue structures develop from the mid-fetal to neonatal period when the liver becomes large and opaque. Recent advances in $3 \mathrm{D}$ imaging combined with tissue clearing techniques (Hama et al. 2011; Yang et al. 2014) enable us to visualize the processes of liver epithelial morphogenesis in 3D (Kaneko et al. 2015; Takashima et al. 2015; Tanimizu et al. 2016). 
Epithelial Morphogenesis during Liver Development

In this section, we summarize molecular mechanisms regulating cellular differentiation of LPCs and epithelial morphogenesis during liver development and the recent progress in our knowledge about in vivo 3D morphogenesis of liver epithelial cells.

\section{OVERVIEW OF LIVER ORGANOGENESIS}

Liver organogenesis starts as the foregut endoderm is stimulated by the fibroblast growth factors (FGFs) and bone-morphogenetic proteins (BMPs) secreted from the adjacent cardiac and the septum transversum mesenchyme, respectively, in mice (Zaret 2002). WNT2bb and retinaldehyde dehydrogenase type 2 (RALDH2), which is the enzyme responsible for retinoic acid (RA) biosynthesis and regulates WNT2bb expression in the lateral plate mesoderm, are involved in specification of the liver in zebrafish and medaka (Ober et al. 2006; Negishi et al. 2010). Around embryonic day 8.0 (E8.0), the foregut endoderm is segregated to $\mathrm{Hhex}^{+} \mathrm{Pdx}{ }^{-}$ and $\mathrm{Hhex}^{-} \mathrm{Pdx} 1^{+}$portions (Spence et al. 2009). $\mathrm{Hhex}^{+} \mathrm{Pdxl}^{-}$tissue develops into the liver bud, whereas Hhex ${ }^{-} \mathrm{Pdx} 1^{+}$tissue generates the extrahepatic biliary structure consisting of extrahepatic bile ducts and gallbladder as well as the ventral pancreas (Bort et al. 2006; Spence et al. 2009). Hepatoblasts in the liver bud expand and migrate into surrounding mesenchymal tissue depending on intrinsic Hhex and Proxl (SosaPineda et al. 2000; Bort et al. 2006) and on growth factors, including human growth factor (HGF) secreted from primitive endothelial cells, FGF10 from fibroblasts, and pleiotrophin/midkine from mesothelial cells (Matsumoto et al. 2001; Berg et al. 2007; Onitsuka et al. 2010). During migration into mesenchymal tissue, hepatoblasts lose epithelial characteristics, which they have established in the foregut (e.g., degradation of the basement membrane and reduction of E-cadherin expression; Sosa-Pineda et al. 2000). Subsequently, hepatoblasts near the portal veins (PVs) are committed to cholangiocytes. In the parenchymal region, hepatoblasts receive oncostatin M (OSM) from hematopoietic cells via gp130 and differentiate to hepatocytes (Kamiya et al. 1999).

\section{IDENTIFICATION OF LIVER STEM/ PROGENITOR CELLS AND THEIR CELLULAR CHARACTERISTICS}

Efforts have been performed to identify specific surface antigens for various types of cells in developing, adult normal, and injured livers, which enable us to isolate LPCs at any developmental stages. Dlk-1 (Tanimizu et al. 2003) and Liv2 (Watanabe et al. 2002) are markers for hepatoblasts, whereas epithelial cell-adhesion molecule (EpCAM) (Okabe et al. 2009), CD13, and CD133 (Kamiya et al. 2009) have been used to identify neonate and adult LPCs (Fig. 2A). In addition to clonal culture systems assessing bidirectional differentiation potential of LPCs, two culture systems that induce hepatocytic or cholangiocytic differentiation have been used to examine molecular mechanism regulating differentiation and morphogenesis of LPCs. Hepatocytic differentiation can be induced by sequential treatment of OSM and Matrigel overlay (Kamiya et al. 1999, 2002). Bipotential LPCs not only acquire gene expression similar to mature hepatocytes but establish some metabolic functions and bile canalicular-like structures (Fig. 2B, top). On the other hand, cholangiocyte differentiation is examined in 3D culture in which LPCs differentiate along the cholangiocyte lineage, establish cholangiocyte-type epithelial polarity, and form the cyst structure with a single lumen (Fig. 2B, bottom) (Tanimizu et al. 2007). Studies using these two culture systems revealed that neonatal $\mathrm{EpCAM}^{+}$ LPCs differentiate hepatocytes and cholangiocytes, whereas adult $\mathrm{EpCAM}^{+}$cells differentiate cholangiocytes but only partly to hepatocytes, indicating that LPCs alter their differentiation potential during development (Tanimizu et al. 2014). It should be pointed out that most of markers used for isolation of adult LPCs are also those for cholangiocytes (Miyajima et al. 2014). Although LPCs can be enriched in $\mathrm{EpCAM}^{+}$or $\mathrm{CD}_{133^{+}}$fraction, identification of novel surface antigens is necessary to distinguish LPCs and cholangiocytes. Recently, we prospectively isolated liver progenitor cells distinctive to LPCs; CD45 ${ }^{-}$TER $119^{-} \mathrm{CD}^{-} 1^{-}$ICAM- $^{+}$ $\mathrm{EpCAM}^{-}$cells efficiently differentiate to mature 
N. Tanimizu and T. Mitaka

A Isolation of liver stem/progenitors

\begin{tabular}{ll}
\hline Stage & Surface markers \\
\hline Fetal & Dlk1, Liv2, CD13 \\
Neonate & EpCAM \\
Adult & EpCAM, CD133 \\
\hline
\end{tabular}

B In vitro culture

Hepatocyte differentiation

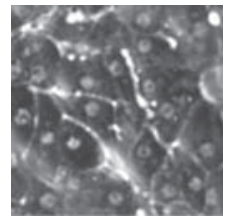

Culture conditions

- Sequential treatment with oncostatin M and Matrigel overlay

Differentiation assay

- Increased expression of metabolic enzymes

- Acquisition of metabolic functions

- Formation of bile canaliculus-like structures

Cholangiocyte differentiation

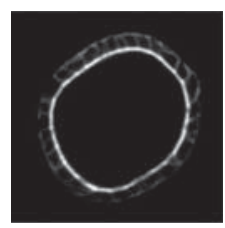

Culture conditions

- 3D culture in ECM gel containing laminin 111

Differentiation assay

- Formation of cystic structures with a single lumen

- Expression and appropriate cellular localization of

cholangiocyte markers

- Directional transport of a substrate of Mdr2

Figure 2. Identification of liver stem/progenitor cells and their in vitro culture systems. (A) Surface markers for fetal, neonatal, and adult liver stem/progenitor cells (LPCs). (B) In vitro culture systems for inducing differentiation of hepatocytes and cholangiocytes. Hepatocyte differentiation is induced by sequential treatment of oncostatin $\mathrm{M}$ and Matrigel overlay. In this culture system, round nuclei and dense cytoplasm become evident. In addition to increased expression of a number of metabolic enzymes, metabolic functions, including albumin secretion, ammonia detoxification, and accumulation of cytoplasmic glycogen as well as cytochrome P450 activities, are induced in this culture condition. Cholangiocyte differentiation is induced in 3D culture in which LPCs are embedded in the extracellular matrix gel containing laminin 111. Cells develop the cyst structure and properly localize cholangiocyte markers, including CK19, EpCAM, aquaporin-1, and integrin $\beta 4$. Cells in the cyst can directionally transport a substrate of multidrug resistance protein 2 (MDR2, ABCB4) from the basal to the apical.

hepatocytes in vitro and in vivo, whereas they have less potential to become cholangiocytes (Tanimizu et al. 2016c). Comparison among these LPC populations and mature liver epithelial cells may help us to understand molecular mechanisms determining a type of epithelial polarity and regulating the liver stem-cell system.

\section{DEVELOPMENT OF INTRAHEPATIC BILE DUCTS}

\section{Tubular Morphogenesis of Cholangiocytes}

Cholangiocytes, differentiated from hepatoblasts, develop IHBD tubules in late fetal and perinatal periods. In a conventional model for mouse IHBD morphogenesis, a single cell layer of cholangiocytes called the ductal plate is first generated around the portal veins (PVs) in E14.5 15.5 livers, which becomes a double cell layer and is progressively reorganized to bile duct tubules from the liver hilum to the periphery (Fig. 3A) (Lemaigre 2003; Antoniou et al. 2009). At an early stage of morphogenesis, cholangiocytes in the ductal plate surround luminal space with neighboring hepatoblasts (Fig. 3B) (Antoniou et al. 2009). Since those structures consist of heterogeneous types of cells, they are called "asymmetric ducts." After hepa- 
A

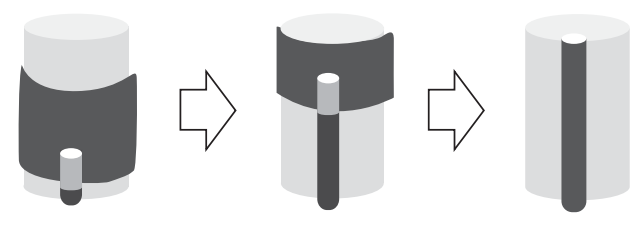

B
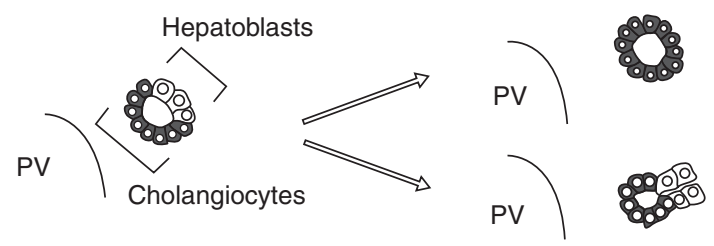

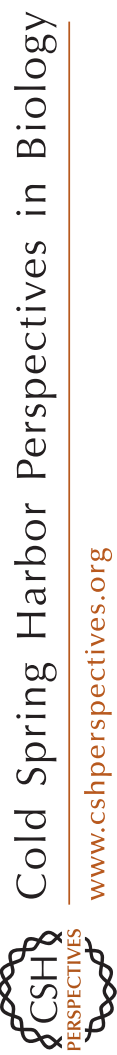

C

8W Liver

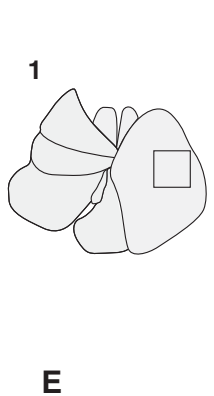

1
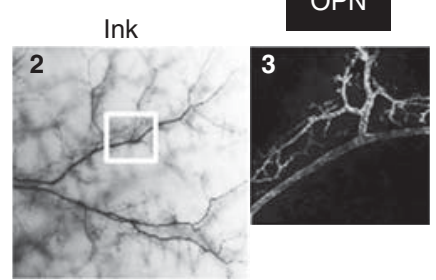

\section{E17 Liver}

\section{OPN}
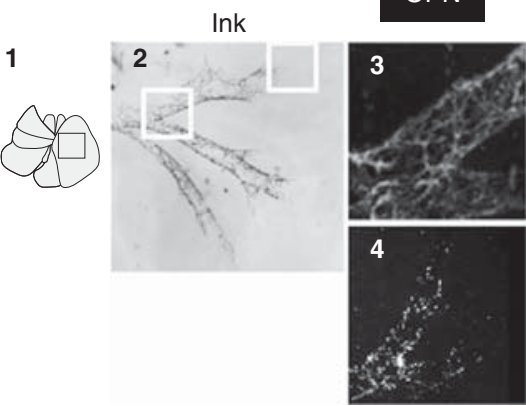

"Homogeneous" luminal network
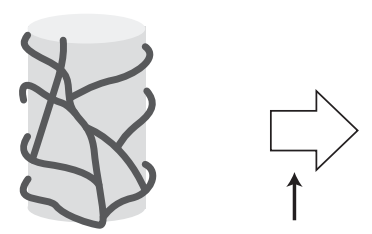

3

"Hierarchical" luminal network
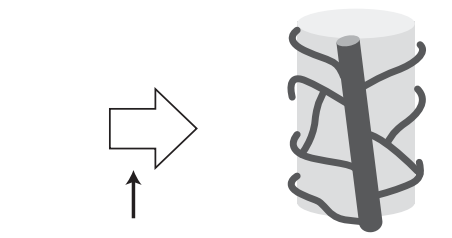

OPN

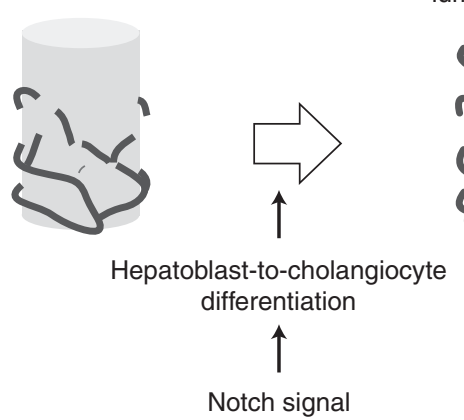

Increase of bile influx

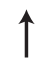

Bile canaliculi formation 
toblasts in "asymmetric ducts" differentiate into cholangiocytes, "symmetric" mature ducts are generated. Alternatively, a layer of cholangiocytes may be rearranged to surround a lumen (Fig. 3B). This type of morphogenesis was observed in a sandwich culture of a liver progenitor cell line in which a monolayer of progenitors folded up and formed tubular structures (Tanimizu et al. 2009). The model that includes the transition from "asymmetric" to "symmetric" ducts well explains tubulogenesis through the formation of intermediate structures that are observed in embryonic liver tissue sections.

Recently, several 3D-imaging techniques have been developed and applied on analyses for liver tissue structures. Retrograde injection of resin into IHBDs from the common bile duct revealed branching structures in the entire liver tissue (Walter et al. 2014). However, only large ducts might be visualized with this method. On the other hand, 3D confocal imaging and retrograde carbon ink injection could visualize not only large ducts but also fine ductular networks and showed that large ducts run along the PVs and small ductules, forming a mesh-like network around the PVs in developing livers as well as in the adult one (Kaneko et al. 2015; Takashima et al. 2015).

We combined confocal imaging and retrograde carbon ink injection into the luminal network to examine tubular morphogenesis of IHBDs (Fig. 3C,D) (Tanimizu et al. 2016). Since small ductules are branched out from large ducts, the mature IHBD structure is referred to as the "hierarchical network" (Fig. 3C). In contrast to the adult liver, the size of the lumen is fine and homogeneous in E17 liver, although the continuous luminal network is established (Fig. 3D2). This luminal network is also evident as the network of $\mathrm{OPN}^{+}$cholangiocytes in $3 \mathrm{D}$ confocal imaging (Fig. 3D3). On the other hand, $\mathrm{OPN}^{+}$cholangiocytes discontinuously exist in the liver periphery in which the luminal network has not yet been established (Fig. 3D4). Extensive analyses of IHBD structures in fetal and neonatal livers have revealed that IHBDs showing the "hierarchical network" thoroughly cover the whole liver tissue by 1 week after birth. Prior to this stage, the "homogeneous network" of IHBDs, consisting of only small ductules, is observed in a substantial region of the periphery of the liver tissue. Based on these results, IHBD morphogenesis can be segregated into three steps. First, cholangiocytes are discontinuously differentiated from hepatoblasts around the PVs (Fig. 3E1), and then they form the continuous homogeneous luminal network consisting of only small ductules (Fig. 3E2). Finally, the homogenous luminal network is dramatically rearranged into the hierarchical mature network between E17 and 18 (Fig. 3E3).

\section{Molecular Mechanisms Governing IHBD Development}

The Notch and transforming growth factor $\beta$ (TGF- $\beta$ ) pathways are two major signals regulating the development of IHBDs. In addition, several transcription factors have been implicated in IHBD development (Table 1; Fig. 4) (Tanimizu and Mitaka 2016).

\section{Jagged1-Notch Pathway}

Biliary atresia, IHBD paucity, and autoimmune diseases, including primary biliary cirrhosis and primary sclerosing cholangitis, are caused by genetic abnormality affecting development and maintenance of the biliary system. Alagille syndrome, a congenital disease showing multiple developmental defects including paucity of IHBDs, is caused by haploinsufficiency of the Notch signaling. In most cases, point mutations in the allele of Jagged-1 lead to generation of truncated protein and reduce the signal (Piccoli and Spinner 2001). Notch2 mutation is also implicated in Alagille syndrome (Kamath et al. 2012). Although Jagged-1 heterozygous mice did not show any major developmental defects (Xue et al. 1999), Notch $2^{+/-}$Jagged $1^{+/-}$mice showed multiple developmental abnormalities similar to human Alagille syndrome, including growth retardation, jaundice, paucity of IHBDs, and abnormal development of kidney (McCright et al. 2002). In addition, components of the Notch signaling have been depleted in liver at different developmental stages. Although the recombination using Cre-loxP sys- 
Epithelial Morphogenesis during Liver Development

Table 1. Mutant mice showing developmental defects in intrahepatic bile ducts (IHBDs) and extrahepatic bile ducts (EHBDs)

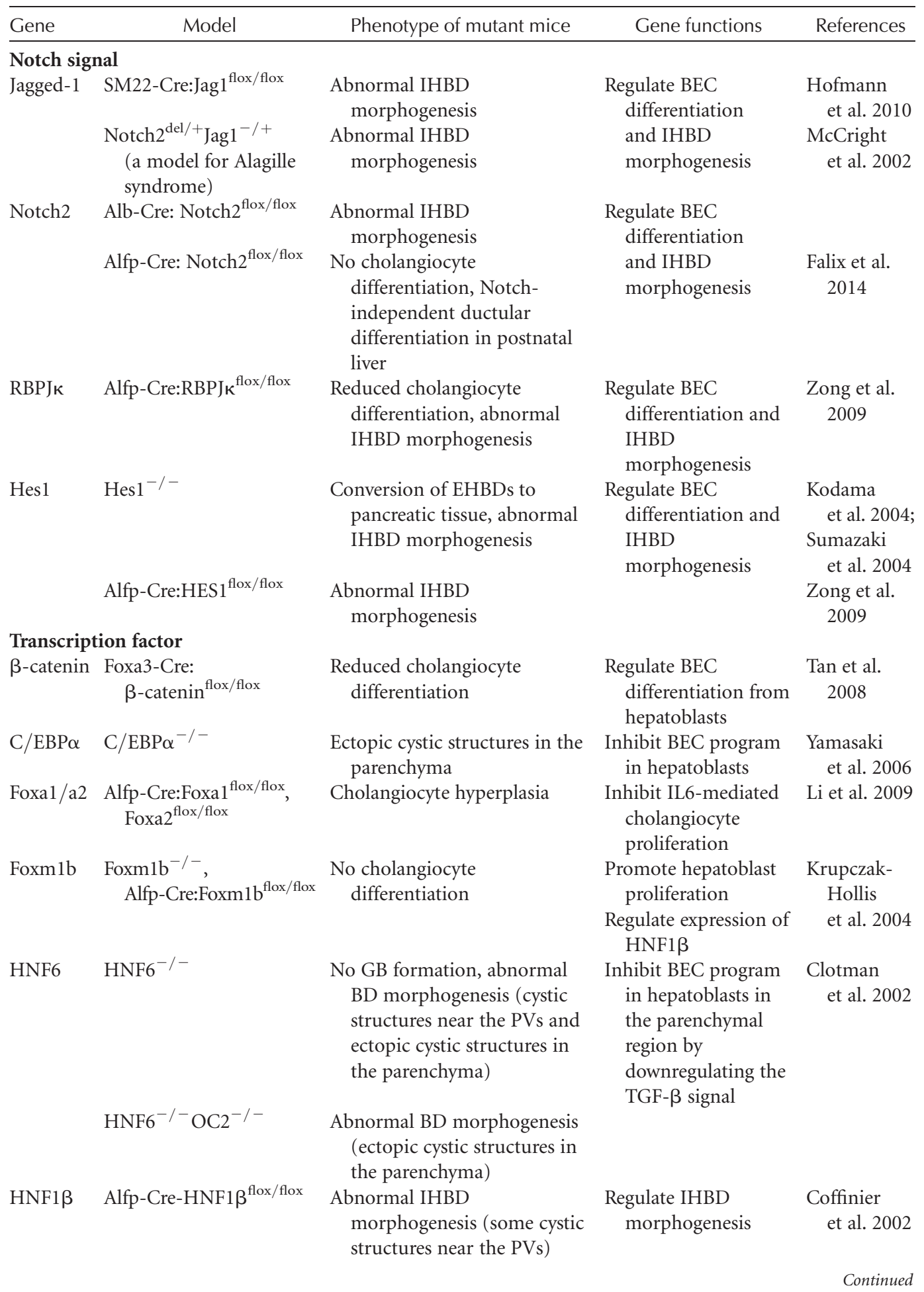


N. Tanimizu and T. Mitaka

Table 1. Continued

\begin{tabular}{|c|c|c|c|c|}
\hline Gene & Model & Phenotype of mutant mice & Gene functions & References \\
\hline \multirow[t]{2}{*}{ Hhex } & FoxA3-Cre:Hhex ${ }^{\text {flox/flox }}$ & $\begin{array}{l}\text { No GB formation, abnormal } \\
\text { IHBD morphogenesis } \\
\text { (ectopic cystic structures in } \\
\text { the parenchyma) }\end{array}$ & $\begin{array}{l}\text { Regulate expression } \\
\text { of HNF1 } \beta, H N F 4 \alpha \text {, } \\
\text { and HNF6 }\end{array}$ & $\begin{array}{l}\text { Hunter et al. } \\
2007\end{array}$ \\
\hline & Alfp-Cre:Hhex ${ }^{\text {flox/flox }}$ & $\begin{array}{l}\text { Abnormal IHBD } \\
\text { morphogenesis (progressive } \\
\text { polycystic phenotype in } \\
\text { postnatal livers) }\end{array}$ & & $\begin{array}{l}\text { Senga et al. } \\
\quad 2012\end{array}$ \\
\hline Prox1 & Foxa3Cre:Prox $1^{\text {flox } / \text { flox }}$ & $\begin{array}{l}\text { Ectopic cystic structures in } \\
\text { parenchyma }\end{array}$ & $\begin{array}{l}\text { Inhibit cholangiocyte } \\
\text { differentiation }\end{array}$ & $\begin{array}{l}\text { Seth et al. } \\
\quad 2014\end{array}$ \\
\hline Sall4 & Not available & $\begin{array}{l}\text { Enhanced cholangiocyte } \\
\text { differentiation }\end{array}$ & $\begin{array}{l}\text { Promote } \\
\text { cholangiocyte } \\
\text { differentiation }\end{array}$ & $\begin{array}{l}\text { Oikawa et al. } \\
2009\end{array}$ \\
\hline Sox 4 & $\begin{array}{l}\text { Alfp-Cre:Sox } 4^{\text {flox } / \text { flox }} \\
\text { Sox } 9^{\text {flox } / \text { flox }}\end{array}$ & $\begin{array}{l}\text { Abnormal cholangiocyte } \\
\text { differentiation and IHBD } \\
\text { morphogenesis }\end{array}$ & $\begin{array}{l}\text { Promote } \\
\text { cholangiocyte } \\
\text { differentiation and } \\
\text { morphogenesis }\end{array}$ & $\begin{array}{l}\text { Poncy et al. } \\
\quad 2015\end{array}$ \\
\hline Sox9 & Alfp-Cre:Sox $9^{\text {flox/flox }}$ & Delay of IHBD morphogenesis & $\begin{array}{l}\text { Promote IHBD } \\
\text { morphogenesis }\end{array}$ & $\begin{array}{l}\text { Antoniou } \\
\text { et al. } 2009\end{array}$ \\
\hline Tbx3 & $\mathrm{Tbx}^{-1-}$ & $\begin{array}{l}\text { Reduced proliferation of } \\
\text { hepatoblasts }\end{array}$ & $\begin{array}{l}\text { Inhibit cholangiocyte } \\
\text { differentiation }\end{array}$ & $\begin{array}{l}\text { Suzuki et al. } \\
2008\end{array}$ \\
\hline \multicolumn{5}{|c|}{ Molecules related to protein sorting and epithelial polarity } \\
\hline Pkhd1 & $\begin{array}{l}\text { Pkhd } 11^{\text {del2/del2 }} \text { (a model } \\
\text { for ARPKH) }\end{array}$ & Progressive IHBD dilatation & $\begin{array}{l}\text { Regulate primary cilia } \\
\text { formation }\end{array}$ & $\begin{array}{l}\text { Woollard } \\
\text { et al. } 2007\end{array}$ \\
\hline Mks1 & $\begin{array}{l}\text { Mks1 }^{-/-} \text {(a model for } \\
\text { Meckel-Gruber } \\
\text { syndrome) }\end{array}$ & $\begin{array}{l}\text { Abnormal IHBD } \\
\text { morphogenesis (ductal plate } \\
\text { is not reorganized into } \\
\text { tubules) }\end{array}$ & $\begin{array}{l}\text { Regulate primary cilia } \\
\text { formation }\end{array}$ & $\begin{array}{l}\text { Weatherbee } \\
\text { et al. } 2009\end{array}$ \\
\hline Wnt5a & Wnt5a $\mathrm{a}^{-/-}$ & $\begin{array}{l}\text { Increased number of } \\
\text { cholangiocytes }\end{array}$ & $\begin{array}{l}\text { Inhibit cholangiocyte } \\
\text { differentiation }\end{array}$ & $\begin{array}{l}\text { Kiyohashi } \\
\text { et al. } 2013\end{array}$ \\
\hline Vps33b & $\begin{array}{l}\text { Zebrafish Vps33b mutant } \\
\text { (a model for ARC } \\
\text { syndrome) }\end{array}$ & Paucity of IHBDs & $\begin{array}{l}\text { Regulate tight junction } \\
\text { formation and } \\
\text { apicobasal polarity }\end{array}$ & $\begin{array}{l}\text { Matthews } \\
\text { et al. } 2005\end{array}$ \\
\hline Cldn $15 b$ & Zebrafish Cld15b mutant & Disorganized IHBD network & $\begin{array}{l}\text { Promote IHBD } \\
\text { morphogenesis }\end{array}$ & $\begin{array}{l}\text { Cheung et al. } \\
2011\end{array}$ \\
\hline
\end{tabular}

ARKHD, Autosomal recessive polycystic kidney and hepatic disease; ARC syndrome, arthorogryposis, renal dysfunction, and cholestasis syndrome; TGF- $\beta$, transforming growth factor $\beta$.

Table is modified from Tanimizu and Mitaka (2016).

tem occurs in a period of time, by using Foxa3Cre, Alfp-Cre, and Alb-Cre mice, depletion of the targeted gene is expected in liver bud, fetal liver, and neonatal liver, respectively. Additionally, Jagged-1 was depleted in mesenchymal cells including periportal fibroblasts, which express Jagged-1 at the onset of IHBD development, by using SM22-Cre mice. Cholangiocyte differentiation from hepatoblasts were partly and almost completely abolished in Foxa3Cre:RBPJK ${ }^{\text {flox/flox }}$ (Zong et al. 2009) and AlfpCre:Notch $2^{\text {flox/flox }}$ mice (Falix et al. 2014), respectively, whereas a reduced but substantial number of cholangiocytes emerged in SM22Cre:Jagged 1 flox/flox (Hofmann et al. 2010), Alfp-Cre:RBPJK ${ }^{\text {flox/flox }}$ (Zong et al. 2009), and 


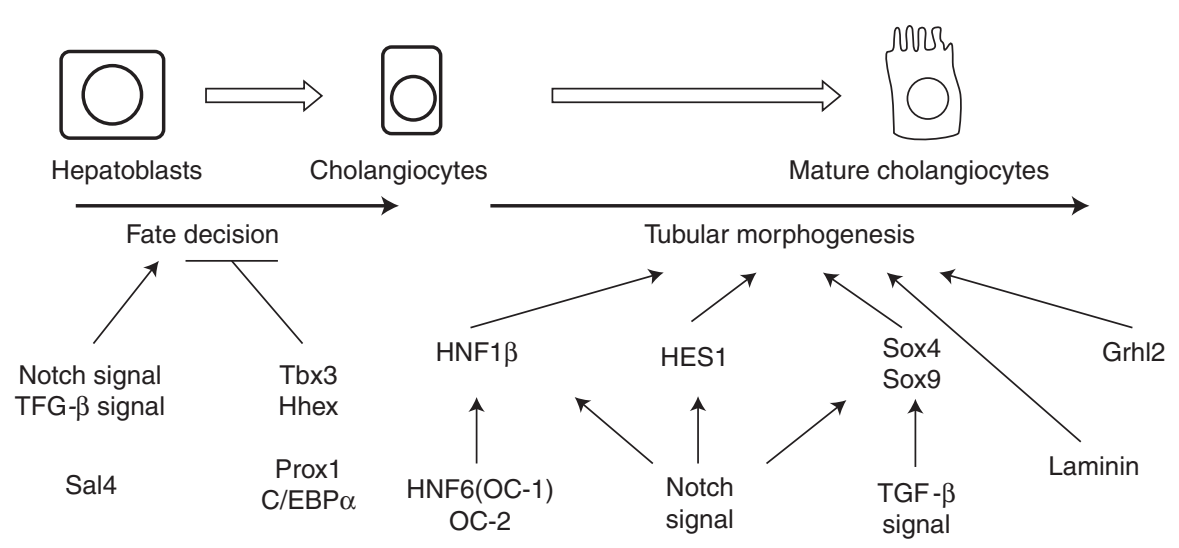

Figure 4. Genes and signaling pathways regulating the development of intrahepatic bile ducts (IHBDs). TGF- $\beta$, Transforming growth factor $\beta$.

Alb-Cre:Notch2 $2^{\text {flox/flox }}$ mice (Geisler et al. 2008; Tchorz et al. 2009). The number of mature duct structures was decreased in the latter three mutant mice, indicating that tubular morphogenesis depends on the Notch signal. These results indicate that the Notch signal mediated by interactions between Jagged $-1^{+}$periportal fibroblasts and Notch $2^{+}$hepatoblasts induces fate decision of hepatoblasts along the cholangiocyte lineage beyond mid-gestation and then later controls tubular morphogenesis.

Extensive analyses of mice lacking an intact Notch signal have further shown that this signal governs the development of IHBDs. However, it remains unknown how this signal regulates tubular morphogenesis of IHBDs. When the signal was inhibited by intraperitoneal injection of DAPT, a $\gamma$-secretase inhibitor, into newborn mice between P2 and 6, the tubular network of IHBDs was not established in the periphery of the liver where cholangiocytes are newly differentiated and undergo tubular morphogenesis in postnatal development (Tanimizu et al. 2016). Even in the presence of DAPT, cholangiocytes normally established the apicobasal polarity in most parts of liver tissue. However, the number of cholangiocytes was significantly reduced in the periphery of the liver and thereby cholangiocytes could not be interconnected to generate the continuous network of IHBD in the presence of DAPT. These results suggest that the appro- priate activation of the Notch signal is crucial to supply enough cholangiocytes to generate the continuous luminal network of IHBDs.

Although hepatoblast-to-cholangiocyte differentiation at the fetal and perinatal stages was totally blocked in Alfp-Cre:Notch $2^{\text {flox/flox }}$ mice and Alb-Cre:HNF6 ${ }^{\text {flox/flox }} \mathrm{RBPJ}^{\text {flox/flox }}$ mice, duct cells emerged around 3W after birth independent of the Notch signal (Falix et al. 2014; Walter et al. 2014). The duct structures that emerged in these mutant mice were similar to those in chronically injured livers associated with expansion of ductular structures, which is called the ductular reaction. Recent works have suggested that part of expanded ductular cells are derived from hepatocytes (Sekiya and Suzuki 2014). Therefore, hepatocytes-to-cholangiocytes conversion may compensate for the defective formation of IHBDs. However, the Notch pathway is the major signal implicated both in ductular expansion and "transdifferentiation" from hepatocytes to cholangiocytes in injured livers (Boulter et al. 2012; Yanger et al. 2013). Therefore, other unknown mechanisms may regulate expansion of duct cells in postnatal livers lacking the Notch signal.

\section{Transcription Factors}

The TGF- $\beta$ signaling pathway has been implicated in biliary differentiation and the expres- 
sion pattern of its components are regulated by HNF6/Onecut-1 (OC-1). The fate determination of hepatoblasts into cholangiocytes was perturbed in mice lacking HNF6 alone or both HNF6 and OC-2. In $\mathrm{HNF}^{-/-}$and $\mathrm{HNF}^{-/-} \mathrm{OC}-2^{-/-}$mice, hepatoblasts showed "hybrid phenotypes" ( positive both for hepatocyte and cholangiocyte markers) and formed cystic structures (Clotman et al. 2002, 2005). Since TGF- $\beta$ RII and negative regulators for the TGF- $\beta$ signal, including $\alpha 2$-macroglobulin and follistatin, increased and decreased, respectively, in $\mathrm{HNF}^{-/-}$OC- $2^{-/}$livers, the TGF- $\beta$ signal was ectopically activated in the parenchymal region, which may induce cholangiocytic characteristics in hepatoblasts in that region.

HNF1 $\beta$, a homeobox transcription factor, is expressed in various tubular structures including IHBDs (Coffinier et al. 1999). Its expression is regulated by HNF6 and the Notch signal in the liver (Clotman et al. 2002; Tanimizu and Miyajima 2004; Zong et al. 2009). In AlfpCre:HNF1 $\beta^{\text {flox } / \text { flox }}$ mice, $\mathrm{CK}^{+}$cholangiocytes emerged near PVs but tubular morphogenesis was severely disturbed (Coffinier et al. 2002). HNF1 $\beta$ regulates proteins localizing in the primary cilia, including polycystic kidney and hepatic disease 1 (Pkhd1). Although the precise mechanisms of how HNF1 $\beta$ regulates IHBD morphogenesis remains unknown, the planar cell polarity might be affected as shown in the kidney lacking HNF1 $\beta$, in which cell divisions along the perpendicular axis dominated those along the axis of elongation, resulting in the lumen expansion and eventually polycystic disease (Verdeguer et al. 2010). Sox9 is regulated by the Notch and TGF- $\beta$ signals and regulates expression of extracellular matrix proteins. IHBD morphogenesis was delayed in Alfp-Cre: Sox $9^{\text {flox/flox }}$ mice (Antoniou et al. 2009), and severer defects in IHBD development were observed in Sox $4^{-/-}$Sox $9^{-/-}$mice (Poncy et al. 2015). These results indicate that redundancy exists between Sox4 and Sox9.

Grainyhead like-2 (Grhl2) is one of mammalian homologs of Drosophila melanogaster grainyhead. GRHL2 is expressed in many types of epithelial cells (Auden et al. 2006). In the liver, GRHL2 is specifically and thoroughly expressed in cholangiocytes in the adult, whereas cholangiocytes forming tubules but not those of peripheral ductules express Grhl2 in the neonatal liver, suggesting that Grhl2 is involved in epithelial maturation and morphogenesis (Fig. 4) (Senga et al. 2012; Tanimizu et al. 2014). Overexpression of Grhl2 in liver progenitor cells augmented the epithelial integrity of cholangiocytes by upregulating claudin 3 (CLDN3) and CLDN4. Grhl2 also upregulated Rab25, a member of the Rab11 family that have been implicated in apical protein sorting and formation of the apical lumen (Casanova et al. 1999; Bryant et al. 2010), and thereby increased CLDN4 localized at tight junctions (TJs) (Senga et al. 2012). By coordinating this molecular network, Grhl2 induced expansion of the apical luminal space in vitro. Furthermore, Grhl2 limited hepatocyte differentiation of LPCs and the conversion of cholangiocyte-to-hepatocyte by inhibiting the expression of $\mathrm{HNF} 4 \alpha, \mathrm{C} / \mathrm{EBP} \alpha$, and $\operatorname{miR} 122$ (Tanimizu et al. 2013, 2014). On the other hand, it has been reported that Grhl2 regulates airway regeneration by controlling differentiation of basal stem cells (Gao et al. 2015) and that Grhl2 suppresses epithelial-mesenchymal transition during neural tube closure (Ray and Niswander 2016). Taken together, Grhl2 may widely regulate not only epithelial morphogenesis but also the lineage plasticity of epithelial cells.

$\mathrm{C} / \mathrm{EBP} \alpha$, Hhex, and Prox1 regulate hepatocyte differentiation and maturation (Kimura et al. 1998; Sosa-Pineda et al. 2000; Bort et al. 2006; Yoshida et al. 2006). However, development of IHBDs was abnormal and cystic structures consisting of hybrid cells emerged in Foxa3-Cre:Hhex ${ }^{\text {flox/flox }}, \mathrm{C} / \mathrm{EBP}^{-/-}$, and Foxa3-Cre:Prox1 ${ }^{\text {flox/flox }}$ mice (Yamasaki et al. 2006; Hunter et al. 2007; Seth et al. 2014). Cystic structure formation is similar to that observed in $\mathrm{HNF}^{-/-}$mice. Abnormal development of IHBDs in mice lacking any one of them indicates that they not only promote hepatocyte characteristics but also suppress cholangiocyte ones in hepatoblasts.

In contrast to mice lacking $\mathrm{HNF} 6, \mathrm{C} / \mathrm{EBP} \alpha$, Hhex, or Prox1, cystic structures did not emerge in the parenchymal region of Alfp- 
Epithelial Morphogenesis during Liver Development

Cre:HNF4 $\alpha^{\text {flox/flox }}$ nor Alfp-Cre:HNF1 $\beta^{\text {flox/flox }}$ livers. Hepatic cords and sinusoids were not properly formed in Alfp-Cre:HNF4 $\alpha^{\text {flox/flox }}$ mice (Parviz et al. 2003). HNF4 $\alpha$ depletion resulted in the loss of junctional proteins such as $\mathrm{ZO} 1$ and E-cadherin, which may be a reason why hepatoblasts do not form cystic structures. Although loss of HNF1 $\beta$ induced cystic structures near PVs, we found that overexpression of HNF1 $\beta$ in liver progenitor cells induced lumen expansion in a sandwich culture in which progenitor cells develop tubular structures (Tanimizu et al. 2009) and in the 3D culture, suggesting that HNF1 $\beta$ is a crucial factor for lumen formation. This result is consistent in that HNF $1 \beta^{-/-}$hepatoblasts do not form cystic structures in Alfp-Cre:HNF1 $\beta^{\text {flox/flox }}$ mice.

\section{Extracellular Matrix Proteins}

Laminin, a heterotrimer of $\alpha, \beta$, and $\gamma$ chains, has been implicated in establishment of epithelial polarity and morphogenesis (Timpl et al. 2000; Sasaki et al. 2004; Yu et al. 2005; Durbeej 2010). The layer of laminin is observed underneath cholangiocytes from the early stage of IHBD development as well as PVs, central veins (CVs), and hepatic arteries (Shiojiri and Sugiyama 2004; Kikkawa et al. 2005). In addition, the extracellular matrix (ECM) layer containing laminin surrounded cystic structures of "hybrid cells" appeared in livers lacking HNF6, Prox1, or C/EBP $\alpha$ (Clotman et al. 2005; Yamasaki et al. 2006; Seth et al. 2014). These results indicate that liver epithelial cells are associated with laminins just after hepatoblasts are committed, even if partly, to the cholangiocyte lineage.

We examined expression and localization of laminin $\alpha 1$ and $\alpha 5$ during IHBD development. Laminin $\alpha 1$ and $\alpha 5$ were detected at the basal side of cholangiocytes in E15.5 liver, whereas only laminin $\alpha 5$ was detected in the adult. In embryonic livers, p75NTR ${ }^{+}$fibroblasts including periportal mesenchymal cells and $\mathrm{EpCAM}^{+}$ cholangiocytes expressed laminin $\alpha 1$ and $\alpha 5$, respectively. These results suggest that laminin $111(\alpha 1 \beta 1 \gamma 1)$ supplied from mesenchymal cells support the beginning of biliary morphogenesis in a paracrine manner, and then laminin $511(\alpha 5 \beta 1 \gamma 1) / 521(\alpha 5 \beta 2 \gamma 1)$ produced by cholangiocytes themselves promote tubular morphogenesis in an autocrine manner (Tanimizu et al. 2012).

This sequential contribution of laminin isoforms to IHBD morphogenesis was shown in the $3 \mathrm{D}$ culture system of liver progenitor cells (Tanimizu et al. 2012). HPPL, a bipotential liver progenitor cell line, developed apicobasal polarity and formed cysts, spheroids with the single central lumen depending on exogenous laminin 111 (Tanimizu et al. 2007). On the other hand, HPPL produced $\alpha 5$-containing laminin (probably laminin 521) and deposited it on the basal domain. In laminin $\alpha 5 \mathrm{KO}$ mice, the delay of IHBD morphogenesis was evident: immature and mature ducts increased and decreased, respectively, in E17.5 laminin $\alpha 5 \mathrm{KO}$ livers. These results suggest that cholangiocytes start tubular morphogenesis depending on laminin 111, whereas they complete it and maintain the tubular structure of IHBDs on laminin 511/521 (Tanimizu et al. 2012).

\section{Physical Stress}

A recent work suggests that blood flow affects lumen formation and morphogenesis of blood vessels (Gebala et al. 2016). Given that IHBDs are the route for the bile juice, their morphogenesis could be affected by the flow of the bile. Notably, fragmented BCs become the continuous network between E17 and 18. We noticed that the color of the intestine changed from white to yellow and expression of Ugt1a1, a crucial enzyme for direct bilirubin formation, was significantly upregulated between E17 and 18 . These results suggest that direct bilirubin production and the bile flow increase between E17 and 18, when the "homogenous fine luminal network" is reorganized to the hierarchical one (Fig. 3E). When a multidrug resistance protein 2 (MRP2, ABCC2) inhibitor was intraperitoneally injected into a pregnant mouse, extension of the BC network was suppressed in the fetus and the structural transition of IHBDs from a "homogenous" to "hierarchical" network was attenuated in the periphery of the liver (Tanimizu et al. 2016). Moreover, it was shown 
that rapid increase of bile volume in the luminal network of IHBDs after bile duct ligation altered the round lumen to the corrugated lumen to increase the surface area (Vartak et al. 2016). These results suggest that physical stress, such as fluid flow is an important factor promoting epithelial tubular morphogenesis.

\section{HEPATOCYTE MORPHOGENESIS}

The apicobasal polarity of hepatocytes is different from that of typical epithelial cells including cholangiocytes (Treyer and Musch 2013). The basal domain without the basal lamina faces the space of Disse, which is generated between hepatocytes and sinusoidal endothelial cells (SECs). In developing livers, BC structures are progressively generated in the fetal liver, and the continuous network of $\mathrm{BC}$ is evident in neonatal livers. Abnormal BC formation caused by genetic mutations eventually lead to cholestasis in the neonatal period. Claudin 1 (CLDN 1) is a gene mutated in neonatal ichthyosis and sclerosing cholangitis (NISCH) syndrome. CLDN1 ${ }^{-/-}$ mice showed abnormal paracellular permeability and defects in BC formation (Hadj-Rabia et al. 2004; Grosse et al. 2012). Mice lacking Radixin, a member of ERM (ezrin-radixinmoesin), lacked microvilli and MRP2 on the BC membrane, resulting in defective bile secretion and hyperbilirubinemia (Kikuchi et al. 2002). Mice lacking liver kinase B1 (LKB1, also known as Par4) in hepatocytes (AlbCre:LKB1 ${ }^{\text {flox/flox }}$ mice) lost the BC localization of the bile salt export pump (BSEP) and did not generate the luminal space of BC (Woods et al. 2011). Furthermore, the luminal space of IHBD was not generated in Alb-Cre:LKB1 ${ }^{\text {flox/flox }}$ mice, suggesting that $\mathrm{BC}$ formation affects tubular morphogenesis of IHBDs.

The process of $\mathrm{BC}$ formation and the underlying molecular mechanisms have been investigated using in vitro culture systems. By sequential treatment with OSM and Matrigel, E14.5 hepatoblasts show hepatocyte morphology and acquire metabolic functions (Fig. 2) (Kamiya et al. 1999, 2002; Kojima et al. 2000). Hepatoblasts first develop typical intercellular junctions, including adherence and tight junctions (TJs) in the presence of OSM depending on K-Ras (Matsui et al. 2002) and then establish BC-like structures with Matrigel overlay. Overexpression of Parlb induced hepatocyte-type polarity in MDCK cells by orienting microtubules via activation of myosin V (Cohen et al. 2004a,b). The $\mathrm{PKA} \rightarrow \mathrm{cAMP} \rightarrow$ LKB1 cascade activates Par $1 \mathrm{~b}$ during $\mathrm{BC}$ formation ( $\mathrm{Fu}$ et al. 2011). In addition to MDCK cells, we showed that taurocholic acid, which activates the $\mathrm{PKA} \rightarrow \mathrm{cAMP} \rightarrow \mathrm{LKB1}$ cascade (Fu et al. 2011), promotes formation of BC-like structures in hepatocytes derived from neonatal LPCs (Tanimizu et al. 2013). However, it remains unclear whether the hepatocyte-type polarity is directly generated or rearranged from a typical intercellular junction during hepatocyte differentiation and maturation.

BCs are initially generated as discontinuous luminal spaces in hepatocyte clusters, where it turns to the continuous network (Fig. 5A). Given that fetal hepatocytes actively proliferate, it is important to coordinate cell division and extension of the BC network. Recently, it was shown that Par1b contributes to maintaining the hepatocyte-type polarity during cell division by controlling the orientation of microtubules (Fig. 5B1) (Slim et al. 2013). In this model, the spindle orientation tends to be perpendicular to an existing BC and thereby abscission does not perturb the BC. On the other hand, asymmetric cytokinesis occurred to share the existing BC to two daughter cells in a culture of a rat hepatocyte cell line (Fig. 5B2) (Wang et al. 2014). In this model, the BC tubule is eventually generated between two rows of hepatocytes. To examine the effect of hepatocyte-ECM interactions in $\mathrm{BC}$ formation, a doublet of rat mature hepatocytes was plated into wells of a culture plate in which the surfaces are separately coated with fibronectin and pluronic acid to make adhesive and nonadhesive surfaces, respectively (Li et al. 2016). When the doublet was inoculated into a well in which the bottom and the side are nonadhesive and adhesive, respectively, the BC space was extended between two cells. It would be interesting to examine whether these mechanisms also operate in vivo to generate the continuous BC network in developing and regenerating livers. 
A
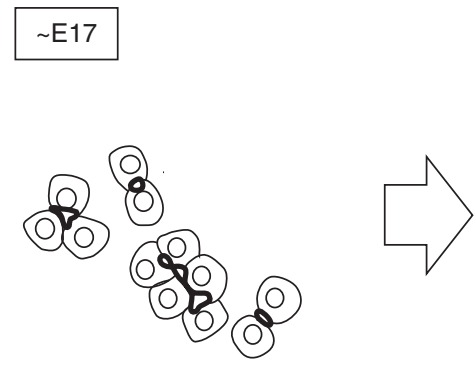

B

1
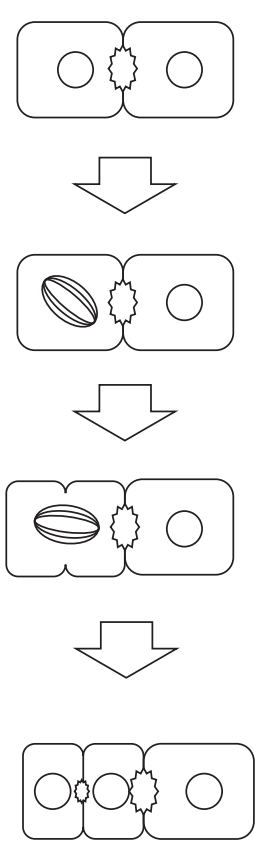

2
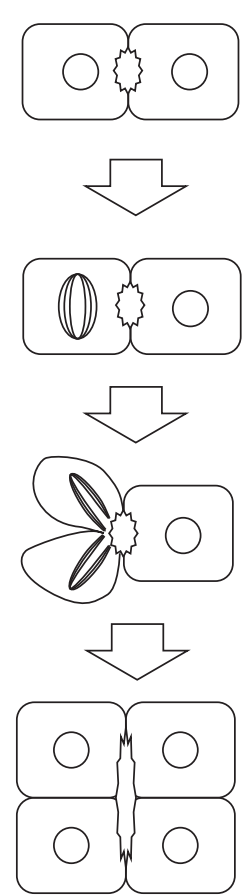

\section{$\sim \mathrm{E} 18$}

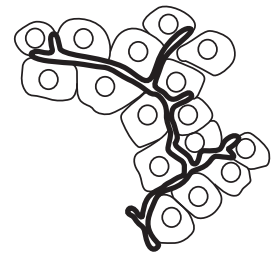

3
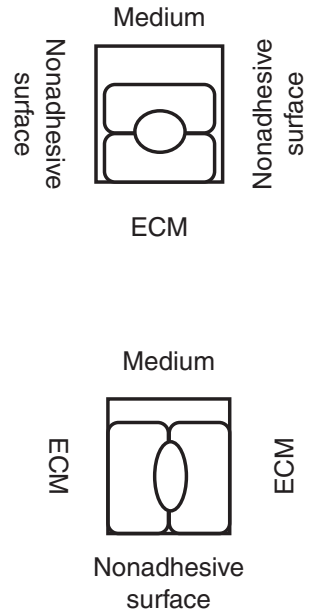

Figure 5. Hepatocyte morphogenesis. (A) Schematic view of the extension of the bile canaliculus (BC) network. BCs are initially generated within hepatocyte clusters. These BCs turn to the continuous network during the following development of the liver. These illustrations depend on observation for E17 and 18 liver sections stained with anti-ZO1 and HNF4 $\alpha$ antibodies. $(B)$ Models for directional extension of the BC. The BC is maintained during cell division, and then a new one is generated between daughter cells. In this model, BC spaces generated independently are eventually interconnected to form the network (panel 1). The spindle is generated parallel to the existing BC. During the oriented cell division, cytokinesis occurs asymmetrically to maintain the BC. In this model, the BC tubule is extended between two rows of hepatocytes (panel 2). When a doublet of rat hepatocytes is inoculated into a well of a culture plate in which the bottom and the side walls are coated with extracellular matrix and nonadhesive substrate, respectively, a round luminal space is expanded between two cells (the upper image in panel 3). On the other hand, when a doublet is plated into a well where the sides are adhesive and the bottom is nonadhesive, a luminal space is elongated between two cells (the lower image in panel 3). 
N. Tanimizu and T. Mitaka

\section{CONCLUDING REMARKS}

Intensive studies using 3D culture systems indicate that establishment of apicobasal polarity, de novo lumen formation, and generation of tubular structures could be proceeded within a homogenous cell cluster if environmental factors including ECM components and growth factors are properly supplied to the culture system (Martin-Belmonte et al. 2008; Bryant et al. 2010; Matsumoto et al. 2014). When an organ becomes functional, connections are correctly established among tissue structures consisting of a one-cell population. In the case of liver, the BC network and the luminal network of IHBDs should be properly connected to drain cytotoxic bile into the duodenum. Interestingly, our recent data suggest that such "inter-tissue" interactions accelerate tubular morphogenesis. Thus, in addition to the precise studies about epithelial morphogenesis of homogeneous cell populations, the contribution of inter-tissue interactions to epithelial morphogenesis and organ development should be investigated. Further technical advances for visualizing $3 \mathrm{D}$ tissue architectures may help us visualize the process of connection between the hepatic cord and IHBDs in fixed and, hopefully, in living mice. A culture system recapitulating both hepatic cord structures and IHBDs in the same culture condition may also become a powerful tool to understand formation of "liver lobule," a functional unit of the liver. Such studies are expected to provide important information to understand tissue morphogenesis proceeding in other epithelial organs.

It is well known that the liver has strong regenerative capability. Hepatocytes and cholangiocytes proliferate and replace damaged tissues on acute injuries, whereas they rearrange tissue architectures to adapt the liver to chronically injured situations. In particular, dynamic rearrangements of IHBDs known as ductular reactions are observed in various types of chronic liver injuries. Notably, IHBDs are differentially rearranged depending on types of injuries (Kaneko et al. 2015). However, we do not know the molecular mechanisms determining how IHBDs alter their luminal network. It is also unknown how cellular properties, including apicobasal polarity are regulated during rearrangement of IHBDs. Comparative studies between tubular morphogenesis of IHBDs and their adaptive rearrangement are expected to reveal novel molecular mechanisms governing formation, maintenance, and regeneration of epithelial tissue structures.

\section{ACKNOWLEDGMENTS}

N.T. is supported by the Ministry of Education, Culture, Sports, Science and Technology, Japan, Grants-in-Aid for Scientific Research (C) (25460271, 16K08716). T.M. is supported by Grants-in-Aid for Scientific Research (B) (21390365, 24390304), and Grants-in-Aid for Exploratory Research (24659591, 26670584).

\section{REFERENCES}

Antoniou A, Raynaud P, Cordi S, Zong Y, Tronche F, Stanger BZ, Jacquemin P, Pierreux CE, Clotman F, Lemaigre FP. 2009. Intrahepatic bile ducts develop according to a new mode of tubulogenesis regulated by the transcription factor SOX9. Gastroenterology 136: 2325-2333.

Auden A, Caddy J, Wilanowski T, Ting SB, Cunningham JM, Jane SM. 2006. Spatial and temporal expression of the Grainyhead-like transcription factor family during murine development. Gene Expr Patterns 6: 964-970.

Berg T, Rountree CB, Lee L, Estrada J, Sala FG, Choe A, Veltmaat JM, De Langhe S, Lee R, Tsukamoto H, et al. 2007. Fibroblast growth factor 10 is critical for liver growth during embryogenesis and controls hepatoblast survival via $\beta$-catenin activation. Hepatology 46: 11871197.

Bort R, Signore M, Tremblay K, Martinez Barbera JP, Zaret KS. 2006. Hex homeobox gene controls the transition of the endoderm to a pseudostratified, cell emergent epithelium for liver bud development. Dev Biol 290: 44-56.

Boulter L, Govaere O, Bird TG, Radulescu S, Ramachandran P, Pellicoro A, Ridgway RA, Seo SS, Spee B, Van Rooijen $\mathrm{N}$, et al. 2012. Macrophage-derived Wnt opposes Notch signaling to specify hepatic progenitor cell fate in chronic liver disease. Nat Med 18: 572-579.

Bryant DM, Datta A, Rodriguez-Fraticelli AE, Peranen J, Martin-Belmonte F, Mostov KE. 2010. A molecular network for de novo generation of the apical surface and lumen. Nat Cell Biol 12: 1035-1045.

Casanova JE, Wang X, Kumar R, Bhartur SG, Navarre J, Woodrum JE, Altschuler Y, Ray GS, Goldenring JR. 1999. Association of Rab25 and Rab1la with the apical recycling system of polarized Madin-Darby canine kidney cells. Mol Biol Cell 10: 47-61.

Cheung ID, Bagnat M, Ma TP, Datta A, Evason K, Moore JC, Lawson ND, Mostov KE, Moens CB, Stainier DY. 2011. 
Regulation of intrahepatic biliary duct morphogenesis by Claudin 15-like b. Dev Biol 361: 68-78.

Clotman F, Lannoy VJ, Reber M, Cereghini S, Cassiman D, Jacquemin P, Roskams T, Rousseau GG, Lemaigre FP. 2002. The onecut transcription factor HNF6 is required for normal development of the biliary tract. Development 129: $1819-1828$.

Clotman F, Jacquemin P, Plumb-Rudewiez N, Pierreux CE, Van der Smissen P, Dietz HC, Courtoy PJ, Rousseau GG, Lemaigre FP. 2005. Control of liver cell fate decision by a gradient of TGF $\beta$ signaling modulated by Onecut transcription factors. Genes Dev 19: 1849-1854.

Coffinier C, Barra J, Babinet C, Yaniv M. 1999. Expression of the vHNF1/HNF1 $\beta$ homeoprotein gene during mouse organogenesis. Mech Dev 89: 211-213.

Coffinier C, Gresh L, Fiette L, Tronche F, Schutz G, Babinet C, Pontoglio M, Yaniv M, Barra J. 2002. Bile system morphogenesis defects and liver dysfunction upon targeted deletion of HNF1ß. Development 129: 1829-1838.

Cohen D, Brennwald PJ, Rodriguez-Boulan E, Musch A. 2004a. Mammalian PAR-1 determines epithelial lumen polarity by organizing the microtubule cytoskeleton. $J$ Cell Biol 164: 717-727.

Cohen D, Rodriguez-Boulan E, Musch A. 2004b. Par-1 promotes a hepatic mode of apical protein trafficking in MDCK cells. Proc Natl Acad Sci 101: 13792-13797.

Durbeej M. 2010. Laminins. Cell Tissue Res 339: 259-268.

Falix FA, Weeda VB, Labruyere WT, Poncy A, de Waart DR, Hakvoort TB, Lemaigre F, Gaemers IC, Aronson DC, Lamers WH. 2014. Hepatic Notch2 deficiency leads to bile duct agenesis perinatally and secondary bile duct formation after weaning. Dev Biol 396: 201-213.

Fu D, Wakabayashi Y, Lippincott-Schwartz J, Arias IM. 2011. Bile acid stimulates hepatocyte polarization through a cAMP-Epac-MEK-LKB1-AMPK pathway. Proc Natl Acad Sci 108: 1403-1408.

Gao X, Bali AS, Randell SH, Hogan BL. 2015. GRHL2 coordinates regeneration of a polarized mucociliary epithelium from basal stem cells. J Cell Biol 211: 669-682.

Gebala V, Collins R, Geudens I, Phng LK, Gerhardt H. 2016. Blood flow drives lumen formation by inverse membrane blebbing during angiogenesis in vivo. Nat Cell Biol 18: 443-450.

Geisler F, Nagl F, Mazur PK, Lee M, Zimber-Strobl U, Strobl LJ, Radtke F, Schmid RM, Siveke JT. 2008. Liver-specific inactivation of Notch2, but not Notch1, compromises intrahepatic bile duct development in mice. Hepatology 48: 607-616.

Grosse B, Cassio D, Yousef N, Bernardo C, Jacquemin E, Gonzales E. 2012. Claudin-1 involved in neonatal ichthyosis sclerosing cholangitis syndrome regulates hepatic paracellular permeability. Hepatology 55: 1249-1259.

Hadj-Rabia S, Baala L, Vabres P, Hamel-Teillac D, Jacquemin E, Fabre M, Lyonnet S, De Prost Y, Munnich A, Hadchouel M, et al. 2004. Claudin-1 gene mutations in neonatal sclerosing cholangitis associated with ichthyosis: A tight junction disease. Gastroenterology 127: 1386-1390.

Hama H, Kurokawa H, Kawano H, Ando R, Shimogori T, Noda H, Fukami K, Sakaue-Sawano A, Miyawaki A. 2011. Scale: A chemical approach for fluorescence imaging and reconstruction of transparent mouse brain. Nat Neurosci 14: $1481-1488$.

Hofmann JJ, Zovein AC, Koh H, Radtke F, Weinmaster G, Iruela-Arispe ML. 2010. Jagged1 in the portal vein mesenchyme regulates intrahepatic bile duct development: Insights into Alagille syndrome. Development 137: 4061-4072.

Hunter MP, Wilson CM, Jiang X, Cong R, Vasavada H, Kaestner KH, Bogue CW. 2007. The homeobox gene Hhex is essential for proper hepatoblast differentiation and bile duct morphogenesis. Dev Biol 308: 355-367.

Kamath BM, Bauer RC, Loomes KM, Chao G, Gerfen J, Hutchinson A, Hardikar W, Hirschfield G, Jara P, Krantz ID, et al. 2012. NOTCH2 mutations in Alagille syndrome. J Med Genet 49: 138-144.

Kamiya A, Kinoshita T, Ito Y, Matsui T, Morikawa Y, Senba E, Nakashima K, Taga T, Yoshida K, Kishimoto T, et al. 1999. Fetal liver development requires a paracrine action of oncostatin $M$ through the gp130 signal transducer. EMBO J 18: 2127-2136.

Kamiya A, Kojima N, Kinoshita T, Sakai Y, Miyaijma A. 2002. Maturation of fetal hepatocytes in vitro by extracellular matrices and oncostatin M: Induction of tryptophan oxygenase. Hepatology 35: 1351-1359.

Kamiya A, Kakinuma S, Yamazaki Y, Nakauchi H. 2009. Enrichment and clonal culture of progenitor cells during mouse postnatal liver development in mice. Gastroenterology 137: 1114-1126.

Kaneko K, Kamimoto K, Miyajima A, Itoh T. 2015. Adaptive remodeling of the biliary architecture underlies liver homeostasis. Hepatology 61: 2056-2066.

Kikkawa Y, Mochizuki Y, Miner JH, Mitaka T. 2005. Transient expression of laminin $\alpha 1$ chain in regenerating murine liver: Restricted localization of laminin chains and nidogen-1. Exp Cell Res 305: 99-109.

Kikuchi S, Hata M, Fukumoto K, Yamane Y, Matsui T, Tamura A, Yonemura S, Yamagishi H, Keppler D, Tsukita S. 2002. Radixin deficiency causes conjugated hyperbilirubinemia with loss of Mrp2 from bile canalicular membranes. Nat Genet 31: 320-325.

Kimura T, Christoffels VM, Chowdhury S, Iwase K, Matsuzaki H, Mori M, Lamers WH, Darlington GJ, Takiguchi M. 1998. Hypoglycemia-associated hyperammonemia caused by impaired expression of ornithine cycle enzyme genes in C/EBP $\alpha$ knockout mice. J Biol Chem 273: 27505-27510.

Kiyohashi K, Kakinuma S, Kamiya A, Sakamoto N, Nitta S, Yamanaka H, Yoshino K, Fujiki J, Murakawa M, KusanoKitazume A, et al. 2013. Wnt5a signaling mediates biliary differentiation of fetal hepatic stem/progenitor cells in mice. Hepatology 57: 2502-2513.

Kodama Y, Hijikata M, Kageyama R, Shimotohno K, Chiba T. 2004. The role of notch signaling in the development of intrahepatic bile ducts. Gastroenterology 127: 1775-1786.

Kojima N, Kinoshita T, Kamiya A, Nakamura K, Nakashima K, Taga T, Miyajima A. 2000. Cell density-dependent regulation of hepatic development by a gp130-independent pathway. Biochem Biophys Res Commun 277: 152158.

Krupczak-Hollis K, Wang X, Kalinichenko VV, Gusarova GA, Wang IC, Dennewitz MB, Yoder HM, Kiyokawa H, Kaestner KH, Costa RH. 2004. The mouse Forkhead Box 
$\mathrm{m} 1$ transcription factor is essential for hepatoblast mitosis and development of intrahepatic bile ducts and vessels during liver morphogenesis. Dev Biol 276: 74-88.

Lemaigre FP. 2003. Development of the biliary tract. Mech Dev 120: 81-87.

Li Z, White P, Tuteja G, Rubins N, Sackett S, Kaestner KH. 2009. Foxa1 and Foxa2 regulate bile duct development in mice. J Clin Invest 119: 1537-1545.

Li Q, Zhang Y, Pluchon P, Robens J, Herr K, Mercade M, Thiery JP, Yu H, Viasnoff V. 2016. Extracellular matrix scaffolding guides lumen elongation by inducing anisotropic intercellular mechanical tension. Nat Cell Biol 18: 311-318.

Martin-Belmonte F, Yu W, Rodriguez-Fraticelli AE, Ewald AJ, Werb Z, Alonso MA, Mostov K. 2008. Cell-polarity dynamics controls the mechanism of lumen formation in epithelial morphogenesis. Curr Biol 18: 507-513.

Matsui T, Kinoshita T, Morikawa Y, Tohya K, Katsuki M, Ito Y, Kamiya A, Miyajima A. 2002. K-Ras mediates cytokine-induced formation of E-cadherin-based adherens junctions during liver development. EMBO J 21: 1021 1030.

Matsumoto K, Yoshitomi H, Rossant J, Zaret KS. 2001. Liver organogenesis promoted by endothelial cells prior to vascular function. Science 294: 559-563.

Matsumoto S, Fujii S, Sato A, Ibuka S, Kagawa Y, Ishii M, Kikuchi A. 2014. A combination of Wnt and growth factor signaling induces Arl4c expression to form epithelial tubular structures. EMBO J 33: 702-718.

Matthews RP, Plumb-Rudewiez N, Lorent K, Gissen P, Johnson CA, Lemaigre F, Pack M. 2005. Zebrafish vps33b, an ortholog of the gene responsible for human arthrogryposis-renal dysfunction-cholestasis syndrome, regulates biliary development downstream of the onecut transcription factor hnf6. Development 132: 5295-5306.

McCright B, Lozier J, Gridley T. 2002. A mouse model of Alagille syndrome: Notch2 as a genetic modifier of Jag1 haploinsufficiency. Development 129: 1075-1082.

Miyajima A, Tanaka M, Itoh T. 2014. Stem/progenitor cells in liver development, homeostasis, regeneration, and reprogramming. Cell Stem Cell 14: 561-574.

Negishi T, Nagai Y, Asaoka Y, Ohno M, Namae M, Mitani H, Sasaki T, Shimizu N, Terai S, Sakaida I, et al. 2010. Retinoic acid signaling positively regulates liver specification by inducing wnt $2 \mathrm{bb}$ gene expression in medaka. Hepatology 51: 1037-1045.

Ober EA, Verkade H, Field HA, Stainier DY. 2006. Mesodermal Wnt $2 \mathrm{~b}$ signalling positively regulates liver specification. Nature 442: 688-691.

Oikawa T, Kamiya A, Kakinuma S, Zeniya M, Nishinakamura R, Tajiri H, Nakauchi H. 2009. Sall4 regulates cell fate decision in fetal hepatic stem/progenitor cells. Gastroenterology 136: 1000-1011.

Okabe M, Tsukahara Y, Tanaka M, Suzuki K, Saito S, Kamiya Y, Tsujimura T, Nakamura K, Miyajima A. 2009. Potential hepatic stem cells reside in $\mathrm{EpCAM}^{+}$cells of normal and injured mouse liver. Development 136: 1951-1960.

Onitsuka I, Tanaka M, Miyajima A. 2010. Characterization and functional analyses of hepatic mesothelial cells in mouse liver development. Gastroenterology 138: $1525-$ 1535.
Parviz F, Matullo C, Garrison WD, Savatski L, Adamson JW, Ning G, Kaestner KH, Rossi JM, Zaret KS, Duncan SA. 2003. Hepatocyte nuclear factor $4 \alpha$ controls the development of a hepatic epithelium and liver morphogenesis. Nat Genet 34: 292-296.

Piccoli DA, Spinner NB. 2001. Alagille syndrome and the Jagged1 gene. Semin Liver Dis 21: 525-534.

Poncy A, Antoniou A, Cordi S, Pierreux CE, Jacquemin P, Lemaigre FP. 2015. Transcription factors SOX4 and SOX9 cooperatively control development of bile ducts. Dev Biol 404: 136-148.

Ray HJ, Niswander LA. 2016. Grainyhead-like 2 downstream targets act to suppress epithelial-to-mesenchymal transition during neural tube closure. Development 143: 11921204.

Sasaki T, Fassler R, Hohenester E. 2004. Laminin: The crux of basement membrane assembly. J Cell Biol 164: 959963.

Sekiya S, Suzuki A. 2014. Hepatocytes, rather than cholangiocytes, can be the major source of primitive ductules in the chronically injured mouse liver. Am J Pathol 184: 1468-1478.

Senga K, Mostov KE, Mitaka T, Miyajima A, Tanimizu N. 2012. Grainyhead-like 2 regulates epithelial morphogenesis by establishing functional tight junctions through the organization of a molecular network among claudin3, claudin4, and Rab25. Mol Biol Cell 23: 2845-2855.

Seth A, Ye J, Yu N, Guez F, Bedford DC, Neale GA, Cordi S, Brindle PK, Lemaigre FP, Kaestner KH, et al. 2014. Proxl ablation in hepatic progenitors causes defective hepatocyte specification and increases biliary cell commitment. Development 141: 538-547.

Shiojiri N, Sugiyama Y. 2004. Immunolocalization of extracellular matrix components and integrins during mouse liver development. Hepatology 40: 346-355.

Slim CL, Lazaro-Dieguez F, Bijlard M, Toussaint MJ, de Bruin A, Du Q, Musch A, van Ijzendoorn SC. 2013. Parlb induces asymmetric inheritance of plasma membrane domains via LGN-dependent mitotic spindle orientation in proliferating hepatocytes. PLoS Biol 11: e1001739.

Sosa-Pineda B, Wigle JT, Oliver G. 2000. Hepatocyte migration during liver development requires Proxl. Nat Genet 25: 254-255.

Spence JR, Lange AW, Lin SC, Kaestner KH, Lowy AM, Kim I, Whitsett JA, Wells JM. 2009. Sox17 regulates organ lineage segregation of ventral foregut progenitor cells. Dev Cell 17: 62-74.

Sumazaki R, Shiojiri N, Isoyama S, Masu M, Keino-Masu K, Osawa M, Nakauchi H, Kageyama R, Matsui A. 2004. Conversion of biliary system to pancreatic tissue in Hes1-deficient mice. Nat Genet 36: 83-87.

Suzuki A, Sekiya S, Buscher D, Izpisua Belmonte JC, Taniguchi H. 2008. Tbx3 controls the fate of hepatic progenitor cells in liver development by suppressing p19ARF expression. Development 135: 1589-1595.

Takashima Y, Terada M, Kawabata M, Suzuki A. 2015. Dynamic three-dimensional morphogenesis of intrahepatic bile ducts in mouse liver development. Hepatology 61: $1003-1011$. 
Epithelial Morphogenesis during Liver Development

Tan X, Yuan Y, Zeng G, Apte U, Thompson MD, Cieply B, Stolz DB, Michalopoulos GK, Kaestner KH, Monga SP. 2008. $\beta$-Catenin deletion in hepatoblasts disrupts hepatic morphogenesis and survival during mouse development. Hepatology 47: 1667-1679.

Tanimizu N, Mitaka T. 2016. Morphogenesis of liver epithelial cells. Hepatol Res 46: 964-976.

Tanimizu N, Miyajima A. 2004. Notch signaling controls hepatoblast differentiation by altering the expression of liver-enriched transcription factors. J Cell Sci 117: 31653174.

Tanimizu N, Nishikawa M, Saito H, Tsujimura T, Miyajima A. 2003. Isolation of hepatoblasts based on the expression of Dlk/Pref-1. J Cell Sci 116: 1775-1786.

Tanimizu N, Miyajima A, Mostov KE. 2007. Liver progenitor cells develop cholangiocyte-type epithelial polarity in three-dimensional culture. Mol Biol Cell 18: 1472-1479.

Tanimizu N, Miyajima A, Mostov KE. 2009. Liver progenitor cells fold up a cell monolayer into a double-layered structure during tubular morphogenesis. Mol Biol Cell 20: $2486-2494$.

Tanimizu N, Kikkawa Y, Mitaka T, Miyajima A. 2012. $\alpha 1$ and $\alpha 5$-containing laminins regulate the development of bile ducts via $\beta 1$ integrin signals. J Biol Chem 287: 28586-28597.

Tanimizu N, Nakamura Y, Ichinohe N, Mizuguchi T, Hirata K, Mitaka T. 2013. Hepatic biliary epithelial cells acquire epithelial integrity but lose plasticity to differentiate into hepatocytes in vitro during development. J Cell Sci 126: 5239-5246.

Tanimizu N, Kobayashi S, Ichinohe N, Mitaka T. 2014. Downregulation of miR122 by grainyhead-like 2 restricts the hepatocytic differentiation potential of adult liver progenitor cells. Development 141: 4448-4456.

Tanimizu N, Kaneko K, Itoh T, Ichinohe N, Ishii M, Mizuguchi T, Hirata K, Miyajima A, Mitaka T. 2016a. Intrahepatic bile ducts are developed through formation of homogeneous continuous luminal network and its $d y-$ namic rearrangement in mice. Hepatology 64: 175-188.

Tanimizu N, Ichinohe N, Ishii M, Kino J, Mizuguchi T, Hirata K, Mitaka T. 2016b. Liver progenitors isolated from adult healthy mouse liver efficiently differentiate to functional hepatocytes in vitro and repopulate liver tissue. Stem Cells 34: 2889-2901.

Tchorz JS, Kinter J, Muller M, Tornillo L, Heim MH, Bettler B. 2009. Notch2 signaling promotes biliary epithelial cell fate specification and tubulogenesis during bile duct development in mice. Hepatology 50: 871-879.

Timpl R, Tisi D, Talts JF, Andac Z, Sasaki T, Hohenester E. 2000. Structure and function of laminin LG modules. Matrix Biol 19: 309-317.

Treyer A, Musch A. 2013. Hepatocyte polarity. Compr Physiol 3: 243-287.

Vartak N, Damle-Vartak A, Richter B, Dirsch O, Dahmen U, Hammad S, Hengstler JG. 2016. Cholestasis-induced adaptive remodeling of interlobular bile ducts. Hepatology 63: 951-964.

Verdeguer F, Le Corre S, Fischer E, Callens C, Garbay S, Doyen A, Igarashi P, Terzi F, Pontoglio M. 2010. A mitotic transcriptional switch in polycystic kidney disease. Nat Med 16: 106-110.
Walter TJ, Vanderpool C, Cast AE, Huppert SS. 2014. Intrahepatic bile duct regeneration in mice does not require Hnf6 or Notch signaling through Rbpj. Am J Pathol 184: 1479-1488.

Wang T, Yanger K, Stanger BZ, Cassio D, Bi E. 2014. Cytokinesis defines a spatial landmark for hepatocyte polarization and apical lumen formation. J Cell Sci 127: 24832492.

Watanabe T, Nakagawa K, Ohata S, Kitagawa D, Nishitai G, Seo J, Tanemura S, Shimizu N, Kishimoto H, Wada T, et al. 2002. SEK1/MKK4-mediated SAPK/JNK signaling participates in embryonic hepatoblast proliferation via a pathway different from NF- $\mathrm{\kappa B}$-induced anti-apoptosis. Dev Biol 250: 332-347.

Weatherbee SD, Niswander LA, Anderson KV. 2009. A mouse model for Meckel syndrome reveals Mks1 is required for ciliogenesis and Hedgehog signaling. Hum Mol Genet 18: 4565-4575.

Woods A, Heslegrave AJ, Muckett PJ, Levene AP, Clements M, Mobberley M, Ryder TA, Abu-Hayyeh S, Williamson C, Goldin RD, et al. 2011. LKB1 is required for hepatic bile acid transport and canalicular membrane integrity in mice. Biochem J 434: 49-60.

Woollard JR, Punyashtiti R, Richardson S, Masyuk TV, Whelan S, Huang BQ, Lager DJ, vanDeursen J, Torres VE, Gattone VH, et al. 2007. A mouse model of autosomal recessive polycystic kidney disease with biliary duct and proximal tubule dilatation. Kidney Int 72: 328-336.

Xue Y, Gao X, Lindsell CE, Norton CR, Chang B, Hicks C, Gendron-Maguire M, Rand EB, Weinmaster G, Gridley T. 1999. Embryonic lethality and vascular defects in mice lacking the Notch ligand Jagged1. Hum Mol Genet 8: 723-730.

Yamasaki H, Sada A, Iwata T, Niwa T, Tomizawa M, Xanthopoulos KG, Koike T, Shiojiri N. 2006. Suppression of C/ $\mathrm{EBP} \alpha$ expression in periportal hepatoblasts may stimulate biliary cell differentiation through increased Hnf6 and Hnflb expression. Development 133: 4233-4243.

Yang B, Treweek JB, Kulkarni RP, Deverman BE, Chen CK, Lubeck E, Shah S, Cai L, Gradinaru V. 2014. Single-cell phenotyping within transparent intact tissue through whole-body clearing. Cell 158: 945-958.

Yanger K, Zong Y, Maggs LR, Shapira SN, Maddipati R, Aiello NM, Thung SN, Wells RG, Greenbaum LE, Stanger BZ. 2013. Robust cellular reprogramming occurs spontaneously during liver regeneration. Genes Dev 27: 719724.

Yoshida Y, Hughes DE, Rausa FM III, Kim IM, Tan Y, Darlington GJ, Costa RH. 2006. C/EBP $\alpha$ and HNF6 protein complex formation stimulates HNF6-dependent transcription by CBP coactivator recruitment in HepG2 cells. Hepatology 43: 276-286.

Yu W, Datta A, Leroy P, O’Brien LE, Mak G, Jou TS, Matlin KS, Mostov KE, Zegers MM. 2005. Betal-integrin orients epithelial polarity via Racl and laminin. Mol Biol Cell 16: 433-445.

Zaret KS. 2002. Regulatory phases of early liver development: Paradigms of organogenesis. Nat Rev Genet 3: 499-512.

Zong Y, Panikkar A, Xu J, Antoniou A, Raynaud P, Lemaigre F, Stanger BZ. 2009. Notch signaling controls liver development by regulating biliary differentiation. Development 136: $1727-1739$. 


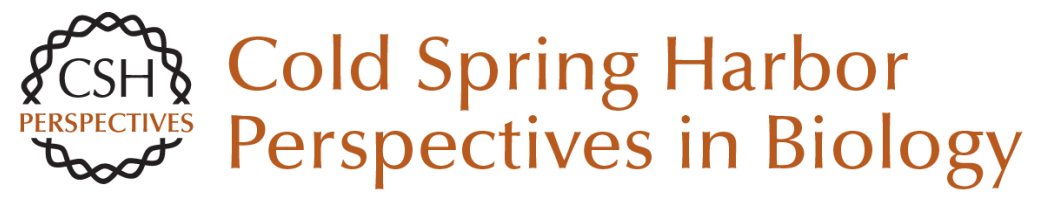

\section{Epithelial Morphogenesis during Liver Development}

Naoki Tanimizu and Toshihiro Mitaka

Cold Spring Harb Perspect Biol 2017; doi: 10.1101/cshperspect.a027862 originally published online February 17, 2017

\section{Subject Collection Cell Polarity}

Regulation of Cell Polarity by Exocyst-Mediated Trafficking Noemi Polgar and Ben Fogelgren

Phosphoinositides and Membrane Targeting in Cell Polarity Gerald R. Hammond and Yang Hong

Trafficking lon Transporters to the Apical Membrane of Polarized Intestinal Enterocytes Amy Christine Engevik and James R. Goldenring

Signaling Networks in Epithelial Tube Formation Ilenia Bernascone, Mariam Hachimi and Fernando Martin-Belmonte

Making Heads or Tails of It: Cell-Cell Adhesion in Cellular and Supracellular Polarity in Collective Migration Jan-Hendrik Venhuizen and Mirjam M. Zegers

Laminins in Epithelial Cell Polarization: Old Questions in Search of New Answers Karl S. Matlin, Satu-Marja Myllymäki and Aki Manninen

Epithelial Morphogenesis during Liver Development

Naoki Tanimizu and Toshihiro Mitaka

Targeting the Mucosal Barrier: How Pathogens Modulate the Cellular Polarity Network Travis R. Ruch and Joanne N. Engel
The Crumbs3 Polarity Protein Ben Margolis

Microtubule Motors in Establishment of Epithelial Cell Polarity Geri Kreitzer and Monn Monn Myat

Role of Polarity Proteins in the Generation and Organization of Apical Surface Protrusions Gerard Apodaca

Polarized Exocytosis Jingwen Zeng, Shanshan Feng, Bin Wu, et al.

Regulation of Transporters and Channels by Membrane-Trafficking Complexes in Epithelial Cells

Curtis T. Okamoto

Membrane Transport across Polarized Epithelia Maria Daniela Garcia-Castillo, Daniel J.-F. Chinnapen and Wayne I. Lencer

Mechanisms of Cell Polarity-Controlled Epithelial Homeostasis and Immunity in the Intestine Leon J. Klunder, Klaas Nico Faber, Gerard Dijkstra, et al.

The Biology of Ciliary Dynamics Kuo-Shun Hsu, Jen-Zen Chuang and Ching-Hwa Sung

For additional articles in this collection, see http://cshperspectives.cshlp.org/cgi/collection/

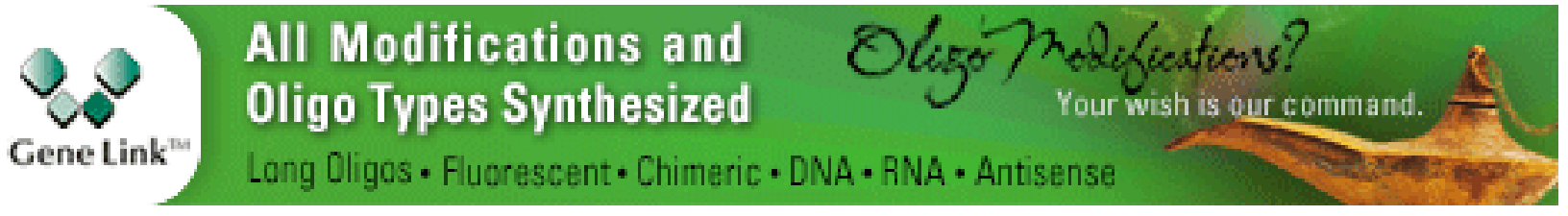

Copyright @ 2017 Cold Spring Harbor Laboratory Press; all rights reserved 